ISSN 1678-4596

\title{
Meta-analysis of scientific studies related to pesticide application techniques-air assistance and adjuvant addition
}

\author{
Metanálise de trabalhos cientificos relacionados à técnicas de aplicação de \\ produtos fitossanitários - assistência de ar e adjuvantes
}

\author{
Gustavo Migliorini de Oliveira ${ }^{\mathrm{I}}$ Marcelo Giovanetti Canteri ${ }^{\mathrm{II}}$ \\ Otavio Jorge Grigoli Abi Saab ${ }^{\text {II }}$
}

\begin{abstract}
The aim of this study was to investigate the effects of air-assisted boom sprayers and addition of adjuvants in the spray solution on control levels of pesticide sprays against weeds and pathogenic fungi by meta-analysis of scientific literature. To perform the meta-analysis, data were collected from the results presented in scientific papers. By these data, a variable was created, denominated as relative control that was used to quantify and test whether the use of air assistance or adjuvants affects the effectiveness of pesticide sprays. This variable was calculated as a difference between percentage of pesticide control in treatments with air assistance or adjuvants and treatments without these spray techniques. Data were analyzed statistically using the Comprehensive Meta-Analysis software. Results showed that the use of air assistance did not have any effect on the control levels of weeds and pathogenic fungi; whereas, the addition of adjuvants increased these levels by $6.45 \%$.
\end{abstract}

Key words: spray tips, application rate, control efficiency.

RESUMO

O objetivo deste trabalho foi estudar, a partir da metanálise de dados de diferentes trabalhos cientificos, o efeito da assistência de ar na barra de pulverização e o efeito da adição de adjuvantes à calda de pulverização, sobre os níveis de controle de plantas daninhas e fungos fitopatogênicos de plantas em pulverizações de produtos fitossanitários. Para a realização da metanálise, foram coletados dados de resultados apresentados em publicações de trabalhos cientificos. A partir desses dados, foi criada uma variável resposta, denominada de diferença de controle relativo, calculada pela diferença entre a percentagem de controle dos tratamentos submetidos ao uso de assistência de ar ou adjuvante e os tratamentos controle, sem os respectivos usos das técnicas de pulverização. Os dados foram analisados estatisticamente por meio do software CMA (Comprehensive Meta-analysis), adotando-se o modelo aleatório. Os resultados demonstraram que a assistência de ar não exerceu efeito algum, nem positivo nem negativo sobre os niveis de controle das plantas daninhas e fungos fitopatogênicos. Já os resultados relativos à adição de adjuvantes evidenciaram aumento médio de $6,45 \% \mathrm{em}$ média nos níveis de controle.

Palavras-chave: ponta de pulverização, taxa de aplicação, eficiência de controle.

\section{INTRODUCTION}

Use of air-assisted boom sprayers and addition of adjuvants to the spray solution are among the factors studied in spray application technique. Air assistance uses forced ventilation at the spray nozzle of the bar to propel spray droplets. This technique, apart from propelling droplets to the target plant, moves the leaves of the plants below the spraying bar, allowing increased drops deposition on lower crop canopy layers, and reduced the possibility of wind-induced drift (BAUER \& RAETANO, 2000; MATTHEWS \& THOMAS, 2000). However, potential reduction of drift with this technique may not occur in all situations; for example, in conditions of little or no ground cover an increased drift might be observed due to air deflection caused by spray (RAETANO \& BAUER, et al., 2004; MATTHEWS, 2000).

Adjuvants are products added to spray solutions to enhance their effectiveness (Decreto $\mathrm{n}^{\circ}$ 4.074, de 04 de janeiro de 2002, BRASIL, 2002) by

\footnotetext{
IUniversidade Estadual de Londrina (UEL), 86047-230, Londrina, PR, Brasil. E-mail: gmigliorini@hotmail.com. Corresponding author.
} IIDepartamento de Agronomia, Universidade Estadual de Londrina (UEL), Londrina, PR, Brasil. 
modifying the chemical action and physicochemical properties of the solution (HAZEN, 2000). Thus, adjuvants are intended to increase the deposition of pesticide spray, its penetration into the leaf tissue, and, in certain cases, reduce risk of drift (SOUZA et al., 2014; CUNHA et al., 2014).

However, scientific studies revealed variations in the degree of control of weeds and phytopathogenic fungi when using air-assisted boom sprayers or adding adjuvants to the spray solution. Thus, meta-analysis is an important tool, since this scientific methodology weighs the results of different studies, considered the variance of these data, and produced a summary of the existing results (LUIZ, 2002). This methodology has been validated in studies involving the application of pesticides, especially those related to plant pathology (MADDEN \& PAUL, 2011), such as the study developed by DALLA LANA et al. (2015), which assessed the relationship between the severity of Asian rust in soybean and losses in productivity.

Thus, the aim of this study was to investigate, using meta-analysis of the scientific papers, the effectiveness of air-assisted boom sprayers and the effectiveness of adjuvants addition to pesticide spray solutions in the control of weeds and phytopathogenic fungi in agricultural crops upon pesticides spraying.

\section{MATERIALS AND METHODS}

To carry out the meta-analysis, results presented in scientific studies were collected through bibliographic surveys of open-access databases available on Internet and in the Annals of the International Symposium of Technology of Application (known in Portuguese as Anais do Simpósio Internacional de Tecnologia de Aplicação) (SINTAG, 2008; 2011; 2013) using the following keywords: application, spraying, adjuvant, and air assistance. In relation to the addition of adjuvants, 13 articles published in scientific journals were used, while in relation to air-assisted boom sprayers, 12 studies were used ( 6 published in scientific journals and 6 from expanded abstracts that had been presented at Symposium).

The surveyed studies evaluated the influence of air assistance and adjuvants on the control of weeds and phytopathogenic fungi. Different units of evaluation measurements used in the surveyed studies were converted into a common unit, control percentage, inferred from the data on treatments testing the use or non-use of air assistance and adjuvants and those without application. Control percentage data were used to create response variables (relative controls, RC). This variable was calculated as the difference between the percentage of the control treatment subjected or not to air-assistance and adjuvant addition and treatments without the respective use (ROSENBERG et al., 2004; MADDEN \& PAUL, 2011). Studies referring to air-assistance resulted in 253 response variables $(\mathrm{n}=253)$, and those referring to adjuvants in 492 variables $(n=492)$.

Number of repetitions and variation coefficient of each respective relative control were also considered, serving as a basis to calculate the measure of variance of each relative control, the standard error (SE) in this case (BORENSTEIN, et al., 2009), according to the equation: $\mathrm{SE}=(((\mathrm{RC} / 2) \times \mathrm{VC}) / 100) / \mathrm{REP} 0,5$; where, $\mathrm{RC}$ is the response variable known as relative control, REP is the number of repetitions, and $\mathrm{VC}$ is the variation coefficient.

Both data on air assistance and data on adjuvant addition were used for an exploratory statistical analysis of distribution and frequency, as well as to perform meta-analyses by means of COMPREHENSIVE META-ANALYSIS (2014) software, in order to quantify the general average effect of the relative controls of each subject studied and its levels of significance. A random model was adopted in both analyses, since the index of heterogeneity (HIGGINS \& THOMPSON, 2002) was more than 1.5 (MADDEN \& PAUL, 2011). Moderator variables such as the type of product applied (fungicide or herbicide) and the volume of application $\left(\mathrm{L} \mathrm{ha}^{-1}\right)$ were also tested. Finally, probability of occurrence of a certain percentage of control was calculated in case the two application techniques themes studied were used (MADDEN \& PAUL, 2011).

\section{RESULTS AND DISCUSSION}

The main objective of the studies surveyed in relation to air-assistance was to test whether the use of this technology, or even different speeds of air stream, influenced the control of phytopathogenic fungi or weeds. Results on the use of air-assistance reveal that most of the calculated relative controls were greater than zero (Figure 1A), with the most commonly observed relative controls ranging between $0 \%$ and $10 \%$ (Figure 1B). However, in general, variances of the relative controls, which showed how far each relative control may vary, can be considered elevated due to the graphical range of standard errors.

The graph showing the distribution and frequency of relative controls (Figure 1A and B) indicated the tendency of air-assistance increased 


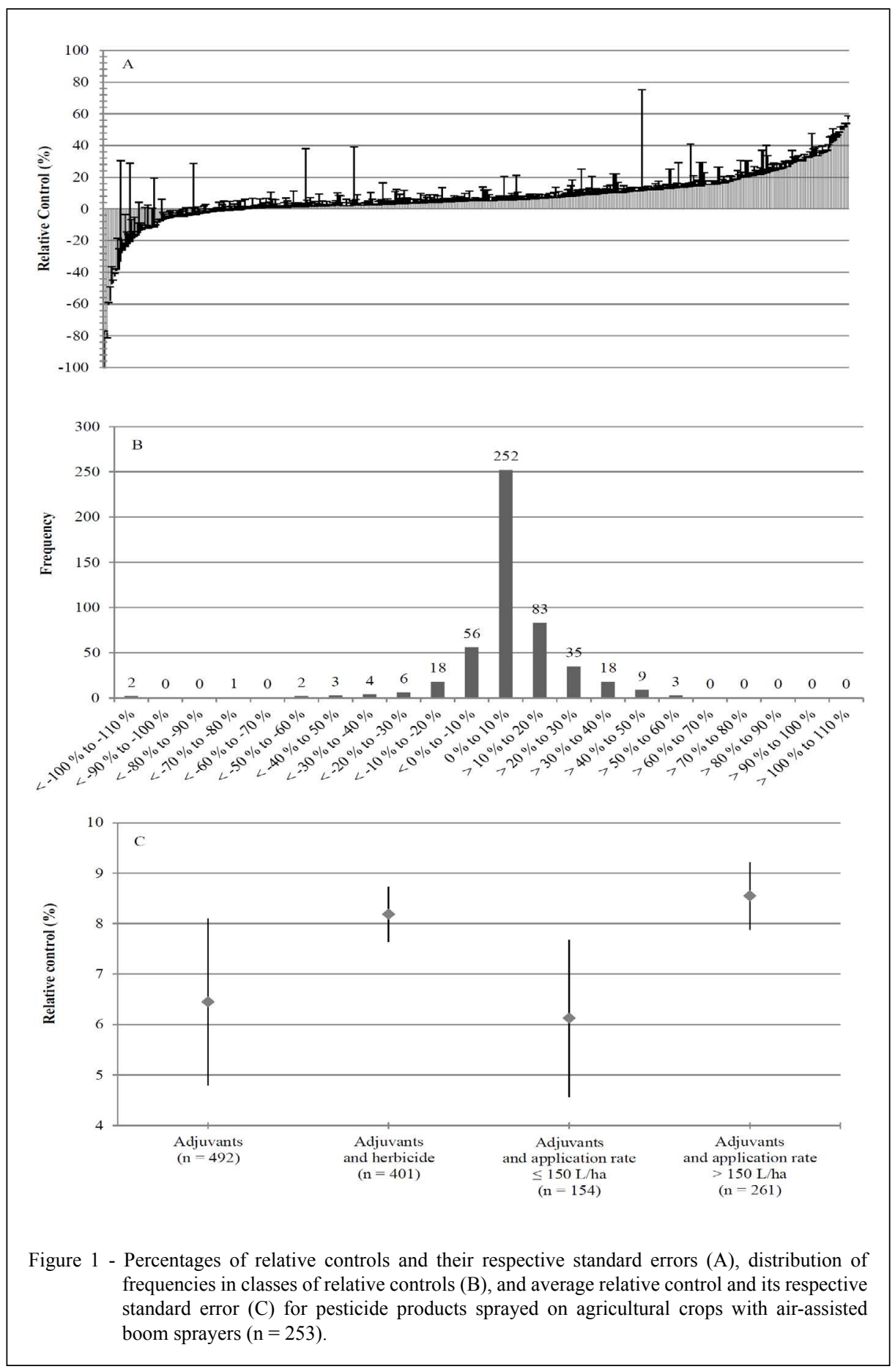

control of weeds and phytopathogenic fungi by around $10 \%$. However, when data were subjected to meta-analysis, taking into consideration the variances of each relative control, the use of air assistance did not influence the control levels against weeds and phytopathogenic fungi. The $p$ value obtained through meta-analysis was 0.8812 ; and thus, it was not possible to affirm the effect of air assistance; although, average relative control was $-0.49 \%$, varying between $-6.95 \%$ and $5.97 \%$ (Figure 1C). In virtue of this result, moderator variables such as the type of product (fungicide or herbicide) and 
the volume applied ( $\leq 150$ and $\left.>150 \mathrm{~L} \mathrm{ha}^{-1}\right)$ were not considered in the analysis and the probability of a certain control percentage was not calculated.

Air assistance, apart from propelling spray droplets, opens the canopy of target plants and delivers the droplets to the lower leaves of the crop while reducing the possibility of wind-induced drift (MATTHEWS, 2000). This notion is supported by the results reported in the study by BAUER \& RAETANO (2000), showing an increase in the deposition of spray solution on the lower leaves of soybean plants. However, in certain cases (little or no ground cover), especially during herbicide applications, there may be an increase in drift due to deflection of air coming from the spraying device (MATTHEWS, 2000; RAETANO \& BAUER, 2004;), which could increase environmental contamination and possibility of enhanced weed control.

In general, considering that there is increased penetration of droplets in plant canopy, it is assumed that air assistance would improve the control levels of the pesticide (AGUIAR JUNIOR, et al., 2011; CHRISTOVAM et al., 2010), especially against phytopathogenic fungi, which usually occur within cultures. However, this type of variable (level of control) is affected by other factors linked to environmental aspects, which increased variance of the data, because the surveyed experiments were performed in the field, which, for instance, statistically increased the sensitivity of this variable compared to other variables related to the deposition of spray solution. This prerogative may explain why the effect of air assistance in the control of noxious organisms to crops was not observed.

Regarding adjuvants, the general objective of the studies that were surveyed was to evaluate the effect of adjuvant application on weed and fungus control by comparing the pesticide products (herbicides and fungicides) and their respective dosages, spray nozzles, application volumes, etc. Increasingly distributed relative controls of this subject showed a positive effect in most cases (Figure 2A), with the most common class between $0 \%$ and $10 \%$ (Figure 2B). Variance of relative controls, generally, might be considered low based on the range of respective errors on the graph.

Graphs of distribution and frequency of relative controls (Figure 2A and B) indicated that the addition of adjuvants may increase the control level by approximately $10 \%$. Meta-analysis of the data, which considered the variance of each relative control, determined the average relative control at $6.45 \% \pm 1.65 \% \quad(P<0.0001)$. In other words, the addition of adjuvants to the spray solution had a positive effect on control of weeds and phytopathogenic fungi (Figure 2C).

Considering moderator variables, average relative control of herbicide applications and spraying increased at application volumes higher than $150 \mathrm{~L} \mathrm{ha}^{-1}$. Even in these cases, standard errors showed lower amplitude variations. However, standard errors did not graphically overlap, indicating that there was a significant difference between moderator variables related to application volumes. Greater amplitude of standard error of the average relative control may be caused by application volumes lower than $150 \mathrm{~L} \mathrm{ha}^{-1}$ (Figure 2C). Applications of fungicide were not included as moderator variables due to the low number of studies surveyed and number of response variables obtained.

Addition of adjuvants to spray solution promotes greater control of weeds and phytopathogenic fungi in agricultural crops due to increased deposition of droplets on the crop canopy and/or reduced levels of drift. Several studies on the addition of adjuvants to the spray solution have confirmed their positive effect on the control of weeds and fungi (SOUZA et al., 2014; CUNHA et al., 2014). This is also evidenced in this survey when summarizing the results of different studies.

Starting with the presupposition that adjuvants are not toxic to weeds and phytopathogenic fungi, effects of these products must be due to altered physicochemical properties of the spray solution (electrical conductivity, viscosity, and surface tension) (SASAKI et al., 2015). Adjuvants, known as spreaders and/or surfactants (commercial names), reduced the surface tension of solution ; and thus, decrease the spray droplet size, while increasing the contact area of these droplets with the plant surface and levels of absorption of pesticides by the leaf tissue (FORSTER et al., 2006; AZEVEDO, 2007; WANG $\&$ LIU, 2007). Another type of adjuvant, named drift reducers, alter the physicochemical properties of the solution by producing larger droplets, which are less subjected to evaporation, and there are other that are recommended for spray solutions containing high levels of dissolved salts.

Therefore, the effect of adjuvants is related to other factors associated with the application technique. For example, BUTLER ELLIS et al. (2004) reported higher retention of spray solution on wheat leaves with a reduced surface tension and attributed this phenomenon to a decrease in the size of sprayed droplets, which is allied with a reduced impact when droplets hit the leaves. CUNHA et al. (2010) verified 


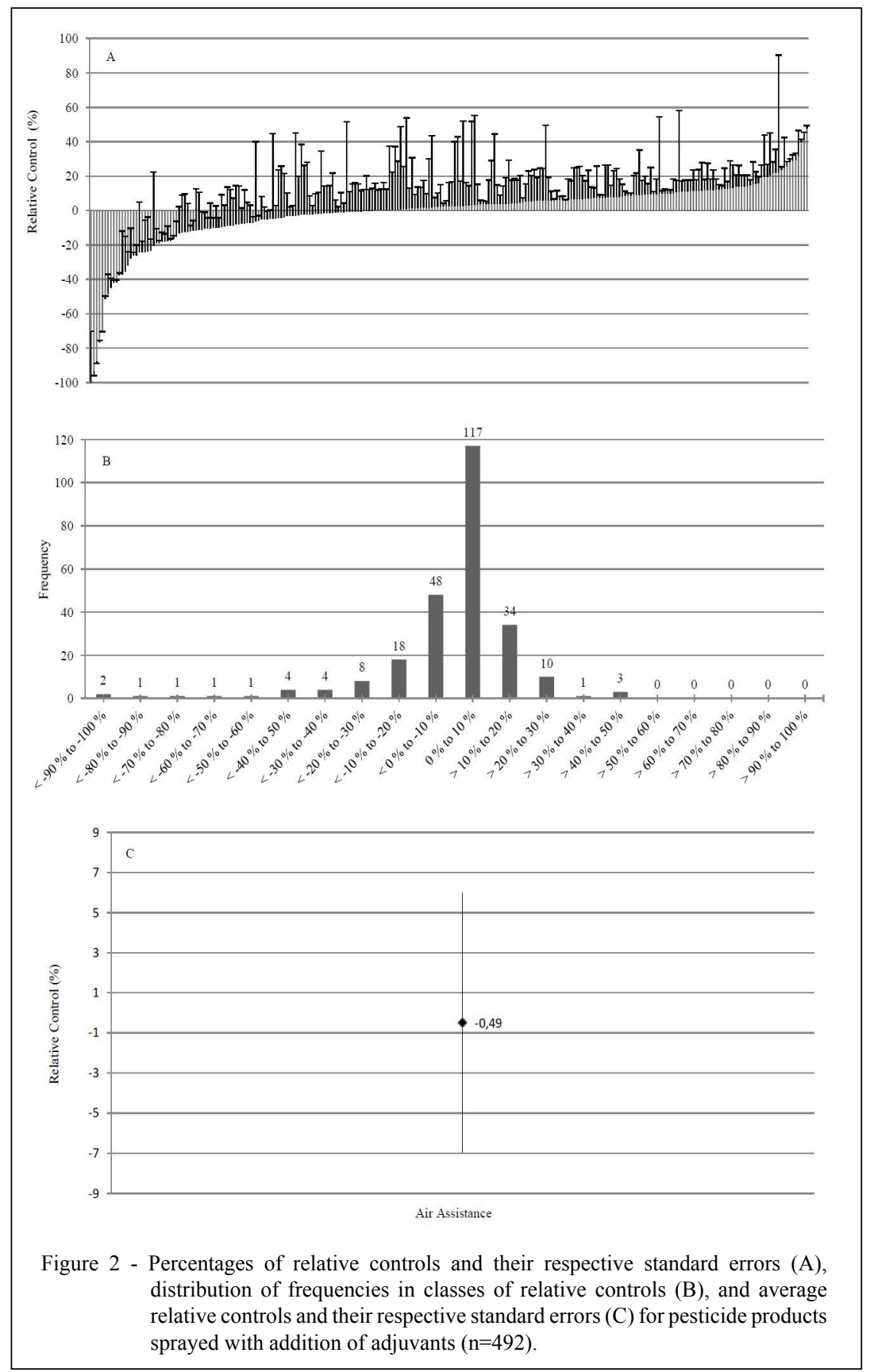

that adjuvants do not change the deposition of droplets on soybean plants but reduce the incidence of Asian soybean rust. This effect depends on the type of spraying nozzle used. Therefore, there is an interaction between adjuvants and other factors related to the application technology, in particular the droplet size and the application volume, which in turn are related to the spraying nozzle and working pressures used (SASAKI et. al., 2015; MOTA \& ANTUNIASSI, 2013). This justified the closeness of average relative controls, when considering the variations between application volumes of $>150$ and $\leq 150 \mathrm{~L} \mathrm{ha}^{-1}$.

Taking into consideration that in this study, the relative control was calculated as the difference between the level of control provided by the addition of adjuvants and that without their use, it may be inferred that the greater the level of control sought through one application containing adjuvant in the solution, the less the chance that this will occur. This notion is confirmed and estimated by the results presented in table 1 . For 
Table 1 - Occurrence probability of relative control as a function of adjuvant addition to spray solution.

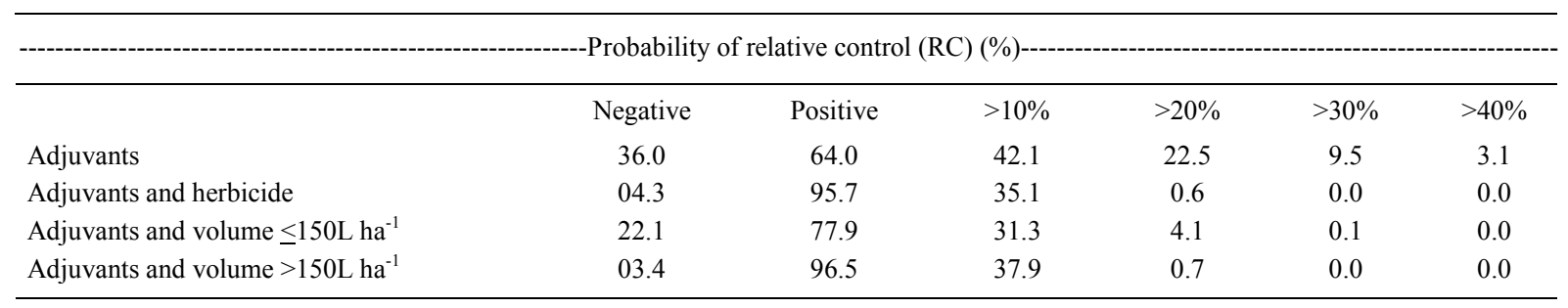

example, the probability to obtain positive levels of control with the addition of adjuvants, regardless of its degree, is $64.02 \%$. However, this probability reduces to $42.15 \%$ and $3.08 \%$ for controls greater than $10 \%$ and $40 \%$, respectively.

Finally, it is emphasized that this study is of general nature because it considers applications of different pesticide products, application techniques, air speed in the bar, and type of adjuvants, in addition to the relatively small number of studies analyzed. However, this study revealed that results from different researches should be considered for a better understanding of the effects of the themes studied. Thus, it is suggested that further studies involving meta-analysis need to be conducted, especially those that will survey a greater number of scientific studies in order to obtain more concise results, leading to more accurate interpretations, since the studies to be analyzed need to include standardized methodology and procedures.

\section{CONCLUSION}

From the meta-analysis of published studies, it is concluded that air assistance did not show either a positive or negative effect on the control of weeds and phytopathogenic fungi in agricultural crops, while the addition of adjuvants in the spray solution increased the control of these noxious organisms on average by $6.45 \%$.

\section{REFERENCES}

AGUIAR JÚNIOR, H.O. et al. Adjuvants and air assistance in sleeve boom sprayer on spray deposition and control of Phakopsora pachyrhizi (Sydow \& Sydow). Summa Phytopathologia, v.37, n.3, p.103-109, 2011. Available from: <http://www.scielo.br/pdf/ sp/v37n3/a04v37n3.pdf>. Accessed: July 21, 2015.

AZEVEDO, L.A.S. Adjuvantes agrícolas para a proteção de plantas. Rio de Janeiro: IMOS, 2011. 264p.
BAUER, F.C.; RAETANO, C.G. Air-assisted sprayer for the evaluation of deposition and losses of pesticide application to soybean crop. Scientia Agricola, v.57, n.2, p.271-276, 2000. Available from: <http://dx.doi.org/10.1590/S010390162000000200012>. Accessed: July 21, 2015.

BORENSTEIN, M. et al. Introduction to Meta-Analyses. John Wiley and Sons, 2009. 450p.

BRASIL, MINISTÉRIO DA AGRICULTURA, PECUÁRIA E ABASTECIMENTO (MAPA). Legislação federal de agrotóxicos (legislação básica e complementar). MARCELO BRESSAN: MAPA/SEFIA, 2012.

BUTLER ELLIS, M.C. et al. The effect of different spray liquids on the foliar retention of agricultural sprays by wheat plants in a canopy. Pest Management Science, v.60, n.8, p.786-794, 2004. Available from: <http://onlinelibrary.wiley.com/doi/10.1002/ ps.875/abstract;jsessionid=54BEDC9F723731C7894D20E307C 63E34.f04t03 >. Accessed: July 21, 2015. doi: 10.1002/ps.875.

CHRISTOVAM, R.S. et al. Air-assistance in sleeve boom spray in the control of soybean rust. Bragantia, v.69, n.1, p.231238, 2010. Available from: <http://dx.doi.org/10.1590/S000687052010000100029>. Accessed: July 21, 2015.

CUNHA, J.P.A.R. et al. Fungicide application technology on Asian soybean rust control: results of an eight-year study in the states of Minas Gerais and Goiás, Brazil. Bioscience Journal, v.30, n.4, p.950-957, 2014. Available from: <http://www.seer.ufu. br/index.php/biosciencejournal/article/view/20907>. Accessed: July 21, 2015.

CUNHA, J.P.A.R.; PERES, T.C.M. Spray nozzle and adjuvant effects on the chemical control of soybean Asian rust. Acta Scientiarum Agronomy, v.32, n.4, p.597-602, 2010. Available from: <http:// www.scielo.br/pdf/asagr/v32n4/a05v32n4>. Accessed: July 21, 2015. doi: 10.4025/actasciagron.v32i4.2502.

FORSTER, W.A. et al. Cuticular uptake of xenobiotics into living plants. Part 2: Influence of the xenobiotic dose on the uptake of bentazone, epoxiconazole and pyraclostrobin, applied in the presence of various surfactants, into Chenopodium album, Sinapis alba and Triticum aestivum leaves. Pesticide Management Science, v.62, p.664-672, 2006. Available from: <http://www. ncbi.nlm.nih.gov/pubmed/16718743>. Accessed: July 21, 2015.

HAZEN, J.L. Adjuvants: terminology, classification, and chemistry. Weed Technology, v.14, p.773-784, 2000. Available from: <http:// wssajournals.org/toc/wete/14/4>. Accessed: Mar. 08, 2016. 
HIGGINS, J.P.; THOMPSON, S.G. Quantifying heterogeneity in a meta-analysis. Statistics in Medicine, v.21, n.11, p.1539-1558, 2002. Available from: <http://psych.colorado. edu/ $\sim$ willcutt/pdfs/Higgins_2002.pdf $>$. Accessed: Mar. 08, 2016. doi: $10.1002 / \mathrm{sim} .11 \overline{8} 6$.

DALLA LANA, F. et al. Meta-analysis of the relationship between crop yield and soybean rust severity. Phytopathology, v.105, n.3, p.303-315, 2015. Available from: <http://www.ncbi.nlm.nih.gov/ pubmed/25244347>. Accessed: July 22, 2015. doi: 10.1094/ PHYTO-06-14-0157-R.

LUIZ, B.A.J. Meta-analysis: definition, applications and synergy with spatial data. Notebooks of Science \& Technology, v.3, p. 407-428, 2002.

MADDEN, L.V.; PAUL, P.A. Meta-analysis for evidence synthesis in plant pathology: an overview. Phytopathology, v.101, n.1, p.16-30, 2011. Available from: <http://apsjournals.apsnet.org/doi/ abs/10.1094/PHYTO-03-10-0069>. Accessed: July 22, 2015. doi: 10.1094/PHYTO-03-10-0069.

MATTHEWS, G.A. Pesticide application methods. 3.ed. Oxford: Blackwell, 2000. 448p.

MATTHEWS, G.A;THOMAS, N. Working towardsmore efficient application of pesticides. Pesticide Management Science, v.56, p.974-976, 2000. Available from: <http://onlinelibrary.wiley. com/doi/10.1002/1526-4998(200011)56:11\%3C974::AIDPS231\%3E3.0.CO;2-4/abstract>. Accessed: July 22 , 2015. doi: 10.1002/1526-4998(200011)56:11<974::AIDPS231>3.0.CO;2-4.
MOTA, A.A.B.; ANTUNIASSI, U.R. Influence of adjuvants on the droplet spectrum of an air induction nozzle. Energia na Agricultura, v.28, n.1, p.1-5, 2013. Available from: <http://dx.doi.org/10.17224/EnergAgric.2013v28n1p01-05>. Accessed: July 22, 2015.

ROSENBERG, M.S. et al. Meta-analysis in plant pathology: synthesizing research results. Phytopatology, v.94, p10131017, 2004. Available from: <http://www.k-state.edu/pdecology/ RosenbergGarrett2004.pdf>. Accessed: July 22, 2015.

RAETANO, C.G.; BAUER, F.C. Spray deposition and spray loss using air-assistance boom on bean plants. Bragantia, v.63, n.2, p.291-297, 2004. Available from: <http://www.scielo.br/scielo. php?script $=$ sci_arttext\&pid=S0006-87052004000200016\&lng=en $\& n r m=$ iso $>$. Accessed: June, 09, 2016.

SASAKI, R.S. et al. Adjuvant on spray solution physical properties droplets spectrum and electrification efficiency using electrostatic spraying. Ciência Rural, v.45, n.2, p.2-7, 2015. Available from: $<$ http://dx.doi.org/10.1590/0103-8478cr20131604>. Accessed: July 22, 2015.

SOUZA, B.J.R. et al. Adjuvants for spraying of fungicides in wheat. Ciência Rural, v.44, n.8, p.1398-1403, 2014. Available from: <http:// dx.doi.org/10.1590/0103-8478cr20131099>. Accessed: July 22, 2015.

WANG, C.J.; LIU, Z.Q. Foliar uptake of pesticides-Present status and future challenge. Pesticide Biochemistry and Physiology, v.87, n.1, p.1-8, 2007. Available from: <http://www.sciencedirect. com/science/article/pii/S0048357506000691>. Accessed: July 22, 2015. doi:10.1016/j.pestbp.2006.04.004. 